\title{
JURNAL BIODJATI
}

http://journal.uinsgd.ac.id/index.php/biodjati

\section{AKTIVITAS ANTIBAKTERI DARI BULU BABI (Diadema setosum) TERHADAP Escherichia coli DAN Staphylococcus aureus}

\author{
Ida Indrawati ${ }^{1}$, Tri Rahayu Hidayat ${ }^{2}$, Nia Rossiana ${ }^{3}$ \\ ${ }^{1,2,3}$ Departemen Biologi Fakultas Matematika dan Ilmu Pengetahuan Alam Universitas Padjadjaran, \\ Jl. Bandung - Sumedang Km 21 Jatinangor 45363 Tel/Fax 0227796412 \\ email:Ida.indrawati81@gmail.com¹,trirahayuhidayat@gmail.com²,niarossiana@yahoo.com ${ }^{3}$
}

\begin{tabular}{l} 
Diterima :02 Mei 2018 \\
Disetujui : 19 November \\
2018 \\
\hline e-ISSN : 2541-4208 \\
p-ISSN : 2548-1606 \\
\hline
\end{tabular}

DOI: 10.15575/biodjati.v3i2.2410
Abstrak. Bulu babi (Diadema setosum) merupakan biota perairan yang memiliki nilai gizi tinggi. Senyawa bioaktif yang dihasilkan oleh bulu babi memiliki potensi untuk dimanfaatkan sebagai senyawa antibakteri alami. Penelitian ini bertujuan untuk mendapatkan aktivitas antibakteri dari ekstrak duri, badan dan gonad bulu babi. Metode penelitian yaitu metode eksploratif dan dianalisis secara deskriptif, melalui tahapan ekstraksi dengan pelarut etanol dan uji sensitivitas dengan metode difusi Kirbybauer. Bulu babi diperoleh dari Pantai Barat Pangandaran, Jawa Barat, Indonesia. Dari ketiga ekstrak bulu babi, ekstrak gonad memiliki aktivitas antibakteri tertinggi pada konsentrasi $80 \%$ dengan zona hambat $8,5 \mathrm{~mm}$ terhadap bakteri Escherichia coli dan konsentrasi $80 \%$ dengan zona hambat $14 \mathrm{~mm}$ terhadap bakteri Staphylococcus aureus, dan didapatkan 3 isolat bakteri dari duri bulu babi dan isolat yang didapatkan adalah koloni putih kekuningan termasuk basil gram positif, koloni putih termasuk basil gram positif dan basil gram negatif serta koloni kekuningan yang termasuk basil pendek gram positif. Isolat 1 lebih efektif terhadap S. aureus dengan zona hambat $11 \mathrm{~mm}$. Isolat 2 lebih efektif terhadap E. coli dengan zona hambat $11 \mathrm{~mm}$. Isolat 3 memiliki zona hambat yang hampir sama antara kedua bakteri uji.

Kata kunci: antibakteri, bulu babi (Diadema setosum), Escherichia coli, Staphylococcus aureus

Abstract. Sea urchin (Diadema setosum) is marine biota that has high nutritional value. Its bioactive compound has potential as a natural antibacterial agent. The research aimed to screen the antibacterial activity from thorn, body and gonad extract of sea urchin. The research method used the explorative and descriptive method, solvent extraction with ethanol and test sensitivity by the diffusion method of Kirby - Bauer. The sea urchin was collect from the west beach in Pangandaran. Jawa Barat, Indonesia. From these extract, gonad extract showed the high antibacterial activity in the concentration $80 \%$ at $8,5 \mathrm{~mm}$ against $E$. coli and also in the concentration $80 \%$ at $14 \mathrm{~mm}$ against $\mathrm{S}$. aureus. Besides be obtained of antibacterial activity, the bacterial from thorn sea urchin is isolated and its result is a white-yellow colony is basil gram-positive, a white colony is basil gram-positive and coccus gram-negative, and then yellow colony is short basil gram positive. Isolate 1 is more effective for $S$. aureus at 11 mm. Isolate 2 is more effective for E. coli at $11 \mathrm{~mm}$ too. Isolate 3 showed 


\section{Jurnal Biodjati, 3 (2) 2018

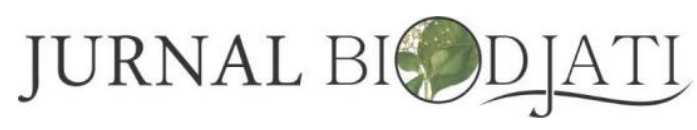

http://journal.uinsgd.ac.id/index.php/biodjati

the same zone of inhibition in the both bacterial.

Keywords: antibacterial, sea urchin (Diadema setosum), Escherichia coli, Staphylococcus aureus

\section{Cara Sitasi}

Indrawati, I., Hidayat, T. R., Rossiana, N. (2018). Aktivitas Antibakteri dari Bulu Babi (Diadema setosum) terhadap Eschericia coli dan Staphylococcus aureus. Jurnal Biodjati, 3(2), 183-192.

\section{PENDAHULUAN}

Secara geografi Indonesia merupakan negara kepulauan dengan kekayaan sumber daya alam laut yang berpotensi untuk dimanfaatkan secara lestari (Leimena, 2002). Bulu babi merupakan salah satu jenis biota perairan laut yang berasal dari filum Echinodermata, penyebaran bulu babi terlihat hampir di seluruh zona perairan. $D$. setosum merupakan salah satu jenis bulu babi yang penyebarannya di seluruh zona terumbu karang (Zakaria, 2013).

Aktivitas antibakteri ditemukan pada bagian tubuh yang berbeda dari green sea urchin dengan menggunakan bakteri uji. Hasil ini menunjukkan bahwa filum Echinodermata salah satunya bulu babi memiliki potensi sebagai antimikroba alami (Haug et al, 2002; Uma \& Parvathavarthini, 2010). Metabolit yang dihasilkan oleh bulu babi dapat dimanfaatkan dalam bidang pengobatan yang berpotensi untuk dimanfaatkan sebagai antibiotik tipe baru karena mengandung senyawa bioaktif (Abubakar et al, 2012). Sebuah studi melaporkan 43\% aktivitas antimikroba berasal dari 83 spesies dari filum Echinodermata yang tidak diidentifikasi yang diperoleh dari pantai barat daya California dan Teluk California menunjukkan adanya aktivitas antimikroba, kemudian sebesar 58\% dari 36 spesies yang tidak diidentifikasi dari Laut Karibia juga menunjukkan adanya aktivitas antimikroba (Li et al, 2010).

E. coli menjadi patogen jika jumlah bakteri dalam saluran pencernaan meningkat dan akan menyebabkan beberapa kasus diare. Hal ini disebabkan karena bakteri E. coli dalam jumlah banyak dapat menghasilkan enterotoksin pada sel epitel (Brown, 2005). S. aureus merupakan penyebab infeksi pada luka dan furunkel terutama pada pasien paska bedah. Ciri khas infeksi yang disebabkan oleh $S$. aureus adalah radang supuratif (bernanah) pada jaringan lokal dan cenderung menjadi abses. Manifestasi klinis yang paling sering ditemukan adalah furunkel pada kulit dan impetigo pada anak-anak (David \& Rubinstein, 2003).

Penelitian ini bertujuan untuk mendapatkan aktivitas antibakteri dari ekstrak duri, badan dan gonad bulu babi sehingga dapat dimanfaatkan untuk perkembangan dibidang kesehatan sebagai antibakteri alami.

\section{BAHAN DAN METODE}

\section{Bahan}

Air fukhsin, alkohol 70\%, alkohol 96\%, akuades, ekstrak bulu babi, karbol gentian violet, kultur bakteri E. coli dan S. aureus, lugol, minyak imersi, $\mathrm{NaCl}$ fisiologis, etanol, dan medium NA (Nutrient Agar).

\section{Metode Penelitian}

Metode penelitian yang digunakan untuk mendapatkan ekstrak bulu babi menggunakan metode eksploratif yang dianalisis secara deskriptif, dengan melakukan tahapan pengambilan sampel bulu babi, pembuatan ekstrak bulu babi dengan pelarut etanol $96 \%$ dan pengujian sifat sensitivitas E. coli dan S. aureus terhadap ekstrak bulu babi. Diameter zona hambat yang terbentuk di sekeliling kertas cakram diukur. 


\section{JURNAL BIDDJATI}

http://journal.uinsgd.ac.id/index.php/biodjati

\section{Sterilisasi Alat dan Bahan}

Semua alat dan bahan yang digunakan pada penelitian ini di autoklaf selama 15 menit pada suhu $121^{\circ} \mathrm{C}$ pada tekanan 1 atm.

\section{Pemurnian Bakteri Uji}

Bakteri uji untuk bakteri gram positif adalah $S$. aureus dan gram negatif $E$. coli dimurnikan dari sediaan dengan diambil satu ose lalu digoreskan pada medium NA miring yang sudah dibuat dalam tabung reaksi, setelah itu diinkubasi selama 24 jam.

\section{Pewarnaan Gram}

Satu ose bakteri diletakan pada kaca objek. Preparat difiksasi, ditetesi zat warna karbol gentian violet dan didiamkan selama 30 detik, setelah itu dibilas dengan akuades. Pada tahap selanjutnya, preparat ditetesi zat pemantek lugol dan didiamkan selama 30 detik lalu dibilas dengan akuades. Preparat ditetesi alkohol 96\% 2 detik dan dibilas dengan akuades kemudian ditetesi zat warna pembanding air fuchsin selama 30 detik, lalu dicuci dengan akuades. Pada tahap akhir, preparat dikeringkan dan ditetesi minyak imersi untuk diamati pada mikroskop Biological Binokuler CX 31 Olympus dengan perbesaran 1000X. Bakteri gram positif berwarna ungu, sedangkan gram negatif berwarna merah.

\section{Ekstraksi Bulu Babi dengan Etanol 96\%}

Sampel bulu babi dicuci, kemudian dikeringkan. Bagian duri, badan, dan gonad dari bulu babi masing-masing ditimbang sebanyak 50 gram, selanjutnya sampel di tumbuk dan dimasukkan kedalam wadah berisi etanol sebanyak $50 \mathrm{ml}$ secara terpisah. Kemudian wadah ditutup dan disimpan selama 24 jam sebelum diproses lebih lanjut.

\section{Pengenceran Ekstrak Bulu Babi}

Sebanyak $4 \mathrm{ml}$ ekstrak bulu babi dimasukkan ke dalam tabung reaksi pertama yang berisi $1 \mathrm{ml}$ akuades kemudian dihomogenkan. Selanjutnya 2,5 ml ekstrak dari tabung reaksi pertama diencerkan ke dalam tabung reaksi kedua yang berisi $2,5 \mathrm{ml}$ akuades dan kemudian dihomogenkan dengan vortek. Kemudian dilakukan hal yang sama pada tabung reaksi selanjutnya, sehingga didapatkan konsentrasi $80,40,20,10,5,2,5$ dan $1,25 \%$.

Setelah itu botol-botol vial steril yang berisi kertas cakram diberi tujuh tetes ekstrak dengan pipet tetes yang berbeda-beda konsentrasinya. Kemudian botol-botol vial dibungkus dengan alumunium foil dan diinkubasi selama 24 jam.

\section{Pembuatan Suspensi Bakteri Uji}

Bakteri uji disiapkan dalam bentuk suspensi ke dalam tabung steril berisi garam fisiologis. Kemudian dipindahkan ke dalam tabung reaksi lain dan dilakukan pengenceran hingga yang distandarkan dengan McFarland $0.5\left(3 \times 10^{8} \mathrm{sel} / \mathrm{ml}\right.$ sampel $)$.

\section{Pembuatan Medium Agar Berisi Bakteri Uji}

Suspensi bakteri dimasukkan kedalam tiga cawan petri steril masing-masing sebanyak $1 \mathrm{ml}$ dengan menggunakan mikropipet, kemudian diisi dengan medium NA steril sebanyak $20 \mathrm{ml}$ pada saat suhu medium sekitar $40^{\circ} \mathrm{C}$. Kemudian dihomogenkan dan didiamkan hingga medium membeku.

\section{Uji Aktivitas Bakteri Uji}

Kertas cakram diletakkan dengan pinset steril di atas permukaan lempeng agar yang sudah dihomogenkan dengan suspensi bakteri uji. Selanjutnya medium diinkubasi selama 24 jam pada suhu $37^{\circ} \mathrm{C}$. Setelah itu, diukur zona 


\section{Jurnal Biodjati, 3 (2) 2018

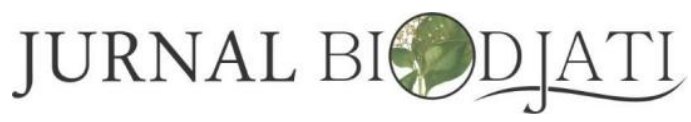

http://journal.uinsgd.ac.id/index.php/biodjati

hambat yang terbentuk pada cawan petri berisi bakteri uji. Standar pengukuran zona hambat, digunakan standar pengamatan sesuai prosedur Stout (2001).

\section{HASIL DAN PEMBAHASAN}

\section{Sensitivitas Bakteri Uji Terhadap Ekstrak Duri Bulu Babi}

Hasil uji aktivitas antibakteri ekstrak duri bulu babi menunjukan adanya aktivitas zat antibakteri dari ekstrak duri bulu babi dengan tingkat sensitivitas bakteri relatif rendah (Tabel 1).

Konsentrasi ekstrak duri bulu babi yang digunakan dalam penelitian ini adalah 80, 40, 20, 10, 5, 2,5 dan 1,25\%. Rata-rata diameter zona hambat hanya berkisar 7-9 mm. Diameter zona hambat menghasilkan sedikit perbedaan pada kedua bakteri uji. Hal ini menunjukkan bahwa bakteri uji mempunyai tingkat resistensi yang berbeda-beda.

Selain menggunakan kertas cakram yang mengandung zat antibakteri dari ekstrak duri bulu babi, sebagai kontrol positif digunakan antibiotik Trimethoprim dan sebagai kontrol negatif digunakan kertas cakram direndam etanol. Zona hambat yang dihasilkan pada antibiotik Trimethoprim berbeda-beda untuk setiap bakteri uji. E. coli menghasilkan zona hambat rata-rata $8 \mathrm{~mm}$ sedangkan S.aureus menghasilkan zona hambat rata-rata $15 \mathrm{~mm}$. Pada kontrol negatif tidak ditemukan adanya zona hambat yang terbentuk.

Ekstrak duri bulu babi menghasilkan zona hambat pada bakteri E. coli. Konsentrasi $80 \%$ menghasilkan zona hambat dengan ratarata diameter $8 \mathrm{~mm}$, konsentrasi 40, 20 dan $10 \%$ menghasilkan diameter rata-rata $7,5 \mathrm{~mm}$, dan untuk konsentrasi 5, 2,5 dan 1,25\% adalah $7 \mathrm{~mm}$.

Hasil zona hambat pada bakteri $S$. aureus terhadap ekstrak duri bulu babi dengan konsentrasi $80 \%$ menghasilkan zona hambat dengan rata-rata diameternya $8,5 \mathrm{~mm}$, konsentrasi $40,20, \quad 10,5, \quad$ dan $2,5 \%$ menghasilkan rata-rata diameter zona hambat $8 \mathrm{~mm}$, dan konsentrasi 1,25\% adalah 7,5 mm. Semua konsentrasi ekstrak duri bulu babi terhadap $S$. aureus menghasilkan sensitivitas yang dikategorikan kurang sensitif.

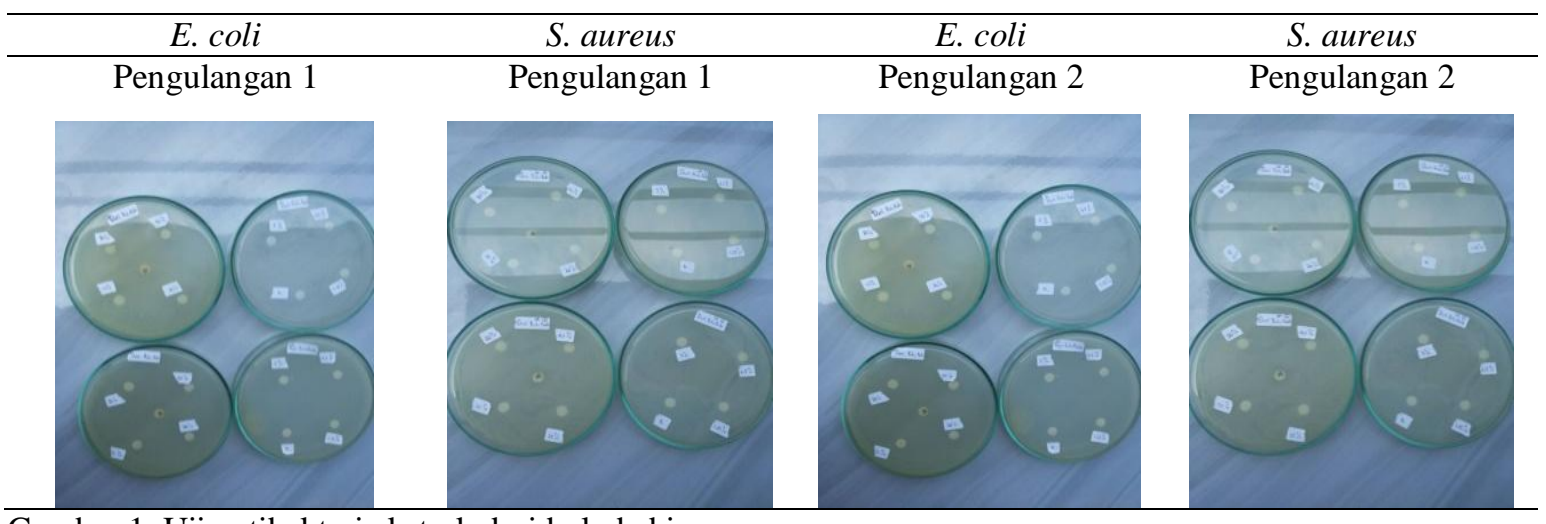

Gambar 1. Uji antibakteri ekstrak duri bulu babi 


\section{JURNAL BIDDJATI}

http://journal.uinsgd.ac.id/index.php/biodjati

Tabel 1. Hasil uji aktivitas antibakteri ekstrak duri bulu babi

\begin{tabular}{|c|c|c|c|c|c|c|c|c|c|}
\hline \multirow{3}{*}{ Bakteri Uji } & \multicolumn{9}{|c|}{ Diameter Zona Hambat (mm) } \\
\hline & \multicolumn{7}{|c|}{ Konsentrasi $(\%)$} & \multirow{2}{*}{$\begin{array}{c}\text { Kontrol + } \\
\text { Trimethoprim }\end{array}$} & \multirow{2}{*}{ Kategori } \\
\hline & 80 & 40 & 20 & 10 & 5 & 2,5 & 1,25 & & \\
\hline \multirow{2}{*}{ E. coli } & 9 & 8 & 8 & 8 & 7 & 7 & 7 & 9 & - \\
\hline & 7 & 7 & 7 & 7 & 7 & 7 & 7 & 7 & - \\
\hline Rata-rata & 8 & 7,5 & 7,5 & 7,5 & 7 & 7 & 7 & 8 & - \\
\hline Kategori & $\mathrm{KS}$ & KS & $\mathrm{KS}$ & $\mathrm{KS}$ & $\mathrm{KS}$ & KS & $\mathrm{KS}$ & $\mathrm{KS}$ & $\mathrm{R}$ \\
\hline \multirow{2}{*}{ S. aeureus } & 9 & 8 & 8 & 8 & 8 & 8 & 8 & 16 & - \\
\hline & 8 & 8 & 8 & 8 & 8 & 8 & 7 & 14 & - \\
\hline Rata-rata & 8,5 & 8 & 8 & 8 & 8 & 8 & 7,5 & 15 & - \\
\hline Kategori & $\mathrm{KS}$ & KS & $\mathrm{KS}$ & $\mathrm{KS}$ & $\mathrm{KS}$ & $\mathrm{KS}$ & $\mathrm{KS}$ & $\mathrm{S}$ & $\mathrm{R}$ \\
\hline
\end{tabular}

Keterangan:

S: Zona hambat termasuk kategori Sensitif diameter zona hambat 10-20 mm

KS: Zona hambat termasuk kategori Kurang sensitif diameter zona hambat 5-10

$\mathrm{R}$ : Zona hambat termasuk kategori Resisten diameter zona hambat $<5 \mathrm{~mm}$.

Konsentrasi $80 \%$ merupakan konsentrasi ekstrak duri bulu babi yang menghasilkan zona hambat terbesar yaitu rata-rata $8 \mathrm{~mm}$ untuk bakteri $E$. coli dan rata-rata $8,5 \mathrm{~mm}$ untuk bakteri $S$. aureus.

S. aureus merupakan bakteri gram positif memiliki lipid cukup tinggi pada dinding selnya, sehingga zat antibakteri akan sulit untuk menembus protoplasmanya. Namun dari hasil pengamatan, kekuatan sensitivitas yang dihasilkan bakteri gram positif lebih sensitif dibandingkan bakteri gram negatif.

\section{Sensitivitas Bakteri Uji Terhadap Ekstrak Badan Bulu Babi}

Sampel kedua yang digunakan adalah ekstrak badan dari bulu babi (Gambar 2). Setelah dilakukan pengamatan, dapat diketahui bahwa ekstrak badan dari bulu babi pun memiliki potensi sebagai antibakteri, meskipun sensitivitas bakteri yang dihasilkan tergolong kurang atau rendah. Diameter zona hambat yang terbentuk dari ekstrak badan bulu babi berkisar antara 7-10 $\mathrm{mm}$. Zona hambat yang dihasilkan pada antibiotik Trimethoprim berbeda-beda untuk setiap bakteri uji. E. coli menghasilkan zona hambat rata-rata $8,5 \mathrm{~mm}$ sedangkan $S$. aureus menghasilkan zona hambat rata-rata
13,5 mm. Pada kontrol negatif tidak ditemukan adanya zona hambat yang terbentuk.

Konsentrasi $80 \%$ merupakan konsentrasi ekstrak badan bulu babi yang menghasilkan zona hambat terbesar yaitu rata-rata $9,5 \mathrm{~mm}$ untuk bakteri $E$. coli, sedangkan konsentrasi ekstrak badan bulu babi yang menghasilkan zona hambat terbesar pada bakteri $S$. aureus adalah konsentrasi $80 \%$ rata-rata zona hambatnya adalah 8,5 mm (Tabel 2). Ekstrak badan bulu babi memiliki potensi sebagai antibakteri baik gram positif maupun gram negatif.

\section{Sensitivitas Bakteri Uji Terhadap Ekstrak Gonad Bulu Babi}

Sampel ketiga yang digunakan adalah ekstrak gonad dari bulu babi (Gambar 3). Bagian dari bulu babi yang biasa dimanfaatkan adalah gonad atau telurnya, baik gonad jantan maupun gonad betina. Bulu babi beraturan mempunyai lima gonad yang tergantung pada daerah aboral (Akerina et al, 2015).

Setelah dilakukan pengamatan, dapat diketahui bahwa ekstrak gonad dari bulu babi pun memiliki potensi sebagai antibakteri, meskipun sensitivitas bakteri yang dihasilkan tergolong kurang atau rendah. Diameter zona hambat yang terbentuk dari ekstrak gonad bulu babi berkisar antara 7-16 mm. Diameter zona 


\section{Jurnal Biodjati, 3 (2) 2018 \\ JURNAL BIODJATI}

http://journal.uinsgd.ac.id/index.php/biodjati

hambat menghasilkan perbedaan pada kedua bakteri uji. Hal ini menunjukkan bahwa masing-masing bakteri uji mempunyai tingkat resistensi yang berbeda-beda.

Zona hambat yang dihasilkan pada antibiotik Trimethoprim berbeda-beda untuk setiap bakteri uji. E. coli menghasilkan zona hambat rata-rata $8,5 \mathrm{~mm}$ sedangkan $S$. aureus menghasilkan zona hambat rata-rata $10,5 \mathrm{~mm}$. Pada kontrol negatif tidak ditemukan adanya zona hambat yang terbentuk untuk E. coli maupun pada bakteri uji S. aureus.

Konsentrasi ekstrak gonad bulu babi $80 \%$ menghasilkan zona hambat pada bakteri E. coli dengan diameter rata-rata $8,5 \mathrm{~mm}$, konsentrasi 40 dan $20 \%$ menghasilkan diameter rata-rata $8 \mathrm{~mm}$, konsentrasi 10 dan 5\% menghasilkan rata-rata diameter zona hambat 7,5 $\mathrm{mm}$, konsentrasi 5 dan 1,25\% menghasilkan rata-rata diameter $7 \mathrm{~mm}$. Semua konsentrasi ekstrak gonad bulu babi menghasilkan sensitivitas yang dikategorikan kurang sensitive (Tabel 3).
Sedangkan untuk hasil zona hambat pada bakteri $S$. aureus terhadap ekstrak gonad bulu babi dengan konsentrasi $80 \%$ adalah rata-rata $14 \mathrm{~mm}$, konsentrasi $40 \%$ adalah rata-rata 13 $\mathrm{mm}$, konsentrasi $20 \%$ menghasilkan rata-rata diameter zona hambat $12,5 \mathrm{~mm}$, konsentrasi 10 dan $5 \%$ menghasilkan zona hambat dengan rata-rata diameter $12 \mathrm{~mm}$ dan konsentrasi $2,5 \%$ adalah $11,5 \mathrm{~mm}$, serta konsentrasi $1,25 \%$ adalah $11 \mathrm{~mm}$. Konsentrasi ekstrak gonad bulu babi terhadap $S$. aureus menghasilkan sensitivitas yang dikategorikan sensitive (Tabel 3). Konsentrasi 80\% merupakan konsentrasi ekstrak gonad bulu babi yang menghasilkan zona hambat terbesar yaitu rata-rata $8,5 \mathrm{~mm}$ untuk bakteri E. coli, sedangkan konsentrasi ekstrak gonad bulu babi yang menghasilkan zona hambat terbesar pada bakteri $S$. aureus adalah konsentrasi $80 \%$ yaitu rata-rata zona hambatnya adalah $14 \mathrm{~mm}$. Sehingga dapat dikatakan bahwa ekstrak gonad bulu babi lebih berpotensi sebagai antibakteri untuk bakteri gram positif karena sifatnya yang lebih sensitif dibandingkan dengan bakteri gram negatif.

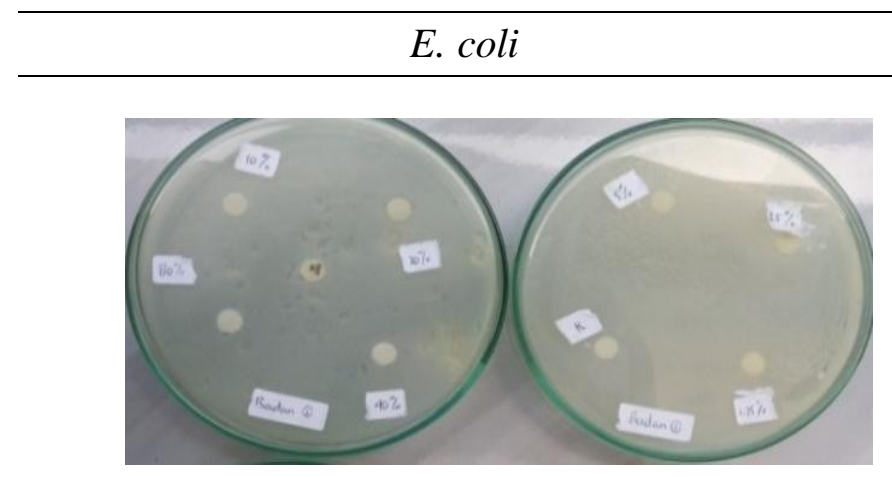

S. aureus

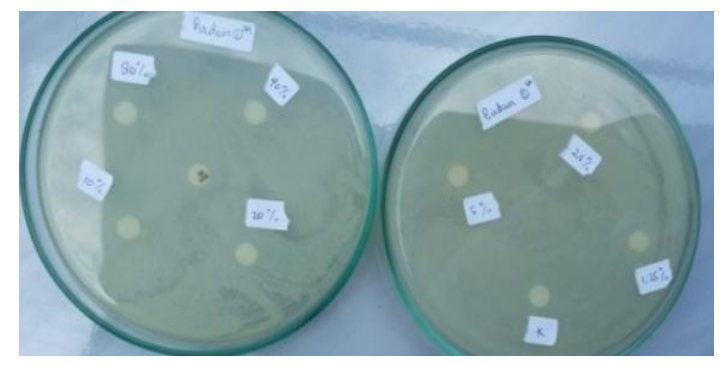

Gambar 2. Uji antibakteri ekstrak badan bulu babi 


\section{Jurnal Biodjati, 3 (2) 2018

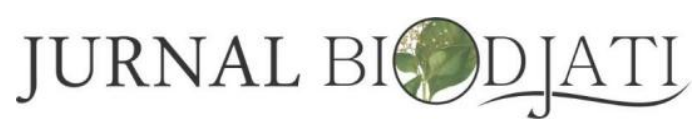

http://journal.uinsgd.ac.id/index.php/biodjati

Tabel 2. Hasil Uji aktivitas antibakteri ekstrak badan bulu babi

\begin{tabular}{|c|c|c|c|c|c|c|c|c|c|}
\hline \multirow{3}{*}{ Bakteri Uji } & \multicolumn{9}{|c|}{ Diameter Zona Hambat (mm) } \\
\hline & \multicolumn{7}{|c|}{ Konsentrasi (\%) } & \multirow{2}{*}{$\begin{array}{c}\text { Kontrol + } \\
\text { Trimethoprim }\end{array}$} & \multirow[t]{2}{*}{ Kategori } \\
\hline & 80 & 40 & 20 & 10 & 5 & 2,5 & 1,25 & & \\
\hline \multirow[b]{2}{*}{ E. coli } & 10 & 8 & 8 & 8 & 8 & 8 & 8 & 9 & - \\
\hline & 9 & 9 & 8 & 8 & 8 & 7 & 7 & 8 & - \\
\hline Rata-rata & 9,5 & 8,5 & 8 & 8 & 8 & 7,5 & 7,5 & 8,5 & - \\
\hline Kategori & KS & KS & KS & KS & KS & KS & $\mathrm{KS}$ & $\mathrm{KS}$ & $\mathrm{R}$ \\
\hline \multirow{2}{*}{ S. aureus } & 9 & 8 & 8 & 8 & 8 & 8 & 7 & 15 & - \\
\hline & 8 & 8 & 8 & 8 & 8 & 8 & 8 & 12 & - \\
\hline Rata-rata & 8,5 & 8 & 8 & 8 & 8 & 8 & 7,5 & 13,5 & - \\
\hline Kategori & KS & $\mathrm{KS}$ & $\mathrm{KS}$ & KS & $\mathrm{KS}$ & $\mathrm{KS}$ & $\mathrm{KS}$ & $\mathrm{S}$ & $\mathrm{R}$ \\
\hline
\end{tabular}

Keterangan:

S: Zona hambat termasuk kategori Sensitif diameter zona hambat 10-20 mm

KS: Zona hambat termasuk kategori Kurang sensitif diameter zona hambat 5-10

$\mathrm{R}$ : Zona hambat termasuk kategori Resisten diameter zona hambat $<5 \mathrm{~mm}$

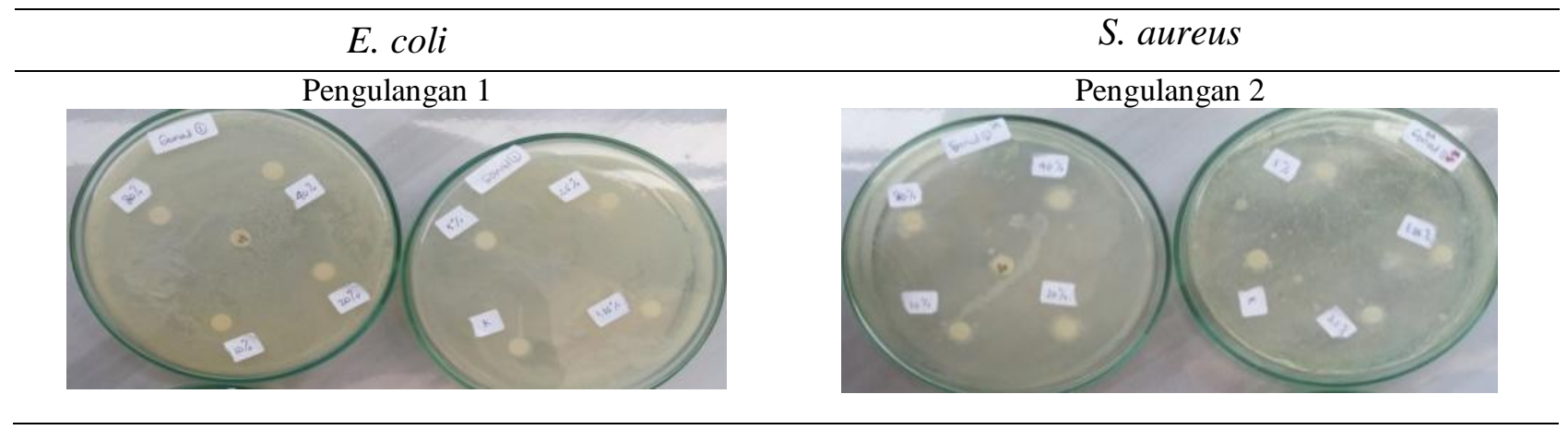

Gambar 3. Uji antibakteri ekstrak gonad bulu babi

Tabel 3. Hasil uji aktivitas antibakteri ekstrak gonad bulu babi

\begin{tabular}{|c|c|c|c|c|c|c|c|c|c|}
\hline \multirow{3}{*}{ Bakteri Uji } & \multicolumn{9}{|c|}{ Diameter Zona Hambat (mm) } \\
\hline & \multicolumn{7}{|c|}{ Konsentrasi (\%) } & \multirow{2}{*}{$\begin{array}{c}\text { Kontrol + } \\
\text { Trimethoprim }\end{array}$} & \multirow{2}{*}{$\begin{array}{c}\text { Kontrol - } \\
\text { Etanol }\end{array}$} \\
\hline & 80 & 40 & 20 & 10 & 5 & 2,5 & 1,25 & & \\
\hline \multirow{2}{*}{ E. coli } & 9 & 8 & 8 & 8 & 7 & 7 & 7 & 8 & 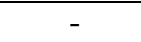 \\
\hline & 8 & 8 & 8 & 7 & 8 & 7 & 7 & 9 & - \\
\hline Rata-rata & 8,5 & 8 & 8 & 7,5 & 7,5 & 7 & 7 & 8,5 & - \\
\hline Kategori & $\mathrm{KS}$ & KS & $\mathrm{KS}$ & $\mathrm{KS}$ & $\mathrm{KS}$ & $\mathrm{KS}$ & $\mathrm{KS}$ & KS & $\mathrm{R}$ \\
\hline \multirow{2}{*}{ S. aureus } & 12 & 11 & 10 & 10 & 10 & 10 & 9 & 9 & - \\
\hline & 16 & 15 & 15 & 14 & 14 & 13 & 13 & 12 & - \\
\hline Rata-rata & 14 & 13 & 12,5 & 12 & 12 & 11,5 & 11 & 10,5 & - \\
\hline Kategori & $\mathrm{S}$ & $\mathrm{S}$ & $\mathrm{S}$ & $\mathrm{S}$ & $\mathrm{S}$ & $\mathrm{S}$ & $\mathrm{S}$ & $\mathrm{S}$ & $\mathrm{R}$ \\
\hline
\end{tabular}

Keterangan:

S: Zona hambat termasuk kategori Sensitif diameter zona hambat 10-20 mm

KS: Zona hambat termasuk kategori Kurang sensitif diameter zona hambat 5-10

$\mathrm{R}$ : Zona hambat termasuk kategori Resisten diameter zona hambat $<5 \mathrm{~mm}$

Berbagai faktor antimikroba yang berasal dari echinodermata yaitu steroidal glikosida, sterol polihidroksilat, lisosom, complement- like substance dan peptida antimikroba (Abubakar et al, 2012). Penelitian yang menggunakan sampel dari filum Echinodermata mem- 


\section{Jurnal Biodjati, 3 (2) 2018 \\ JURNAL BIDDJATI}

http://journal.uinsgd.ac.id/index.php/biodjati

peroleh hasil yang sesuai dengan penelitian ini yakni mengandung komponen bioaktif triterpenoid, steroid, dan saponin pada ekstrak etil asetat dan metanol, dan tidak terdeteksi pada ekstrak n-heksana (Septiadi et al, 2013). Saponin memiliki peran dalam antibakteri dengan mekanisme kerjanya mengganggu permeabilitas membran sel bakteri, sehingga terjadi bakterilisis pada sel bakteri yang ditandai dengan pecahnya membran sel (Pranoto et al, 2012). Senyawa ini juga berperan dalam proses reproduksi untuk jenis lain dari Echinodermata yakni bintang laut dan teripang (Septiadi et al, 2013). Senyawa bioaktif yang berasal dari golongan steroid dan triterpenoid juga memiliki potensi sebagai antibakteri. Pertumbuhan bakteri akan dihambat dengan cara penghambatan sintesis protein dan menyebabkan perubahan komponen-komponen penyusun sel bakteri itu sendiri (Rosyidah et al, 2010).

\section{Hasil Isolasi Bakteri dari Duri Bulu Babi}

Hasil isolasi bakteri dari duri babi didapatkan sebanyak tiga isolat yang diamati secara makroskopik maupun mikroskopik (Tabel 4)

Bulu babi memiliki cangkang yang keras, $95 \%$ bagian tubuh bulu babi didominasi oleh duri-duri yang sangat rapuh. Duri ini digunakan untuk bergerak, melindungi diri, serta mencapit makanan, dan untuk jenis-jenis tertentu mengandung racun. Toksin yang dihasilkan bulu babi dapat dimanfaatkan dalam bidang pengobatan yang berpotensi sebagai antibiotik (Abubakar et al, 2012).

Tabel 4. Hasil isolasi bakteri dari duri bulu babi

\begin{tabular}{lll}
\hline No & \multicolumn{1}{c}{ Pengamatan Makroskopik } & \multicolumn{1}{c}{ Pengamatan Mikroskopik } \\
\hline 1 & $\begin{array}{l}\text { Koloni putih kekuningan, bentuk tidak beratu- } \\
\text { ran, pinggiran bergerigi elevasi rata. }\end{array}$ & Basil, gram positif \\
2 & $\begin{array}{l}\text { Koloni putih, pinggiran rata, elevasi cembung. } \\
\text { Koloni kekuningan, bentuk bulat, pinggiran rata, } \\
\text { elevasi cembung. }\end{array}$ & $\begin{array}{l}\text { Basil-gram positif dan kokus gram negatif } \\
\text { Basil, gram positif }\end{array}$ \\
\hline
\end{tabular}

\begin{tabular}{lll}
\hline Isolat & Makroskopik & Mikroskopik (P:1000X) \\
\hline 1 & & \\
2 & & \\
3 & & 1
\end{tabular}

Gambar 4. Hasil isolasi bakteri dari duri bulu babi 


\section{Jurnal Biodjati, 3 (2) 2018

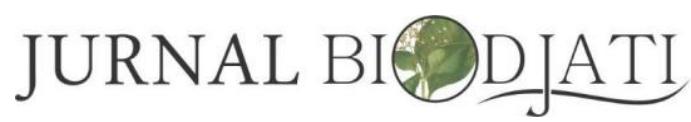

http://journal.uinsgd.ac.id/index.php/biodjati

Hasil isolasi bakteri duri bulu babi, didapatkan tiga koloni bakteri yang berbeda. Isolat 1 secara makroskopik koloninya berwarna putih kekuningan, bentuknya tidak beraturan, pinggiran bergerigi dan elevasi rata. Setelah dilakukan pemurnian ke agar miring, maka dilakukan pewarnaan gram. Secara mikroskopik isolat 1 memiliki bentuk basil panjang dengan warna ungu yang menandakan gram positif. Isolat 2 secara makroskopik koloni berwarna putih, pinggiran rata dengan elevasi cembung, secara mikroskopiknya berbentuk basil panjang berwarna ungu (gram positif) dan kokus berwarna merah (gram negatif). Isolat 3 secara makroskopik memiliki koloni kekuningan, bentuknya bulat dengan pinggiran rata dan elevasinya cembung. Secara mikroskopiknya berbentuk basil pendek berwarna ungu (gram positif).
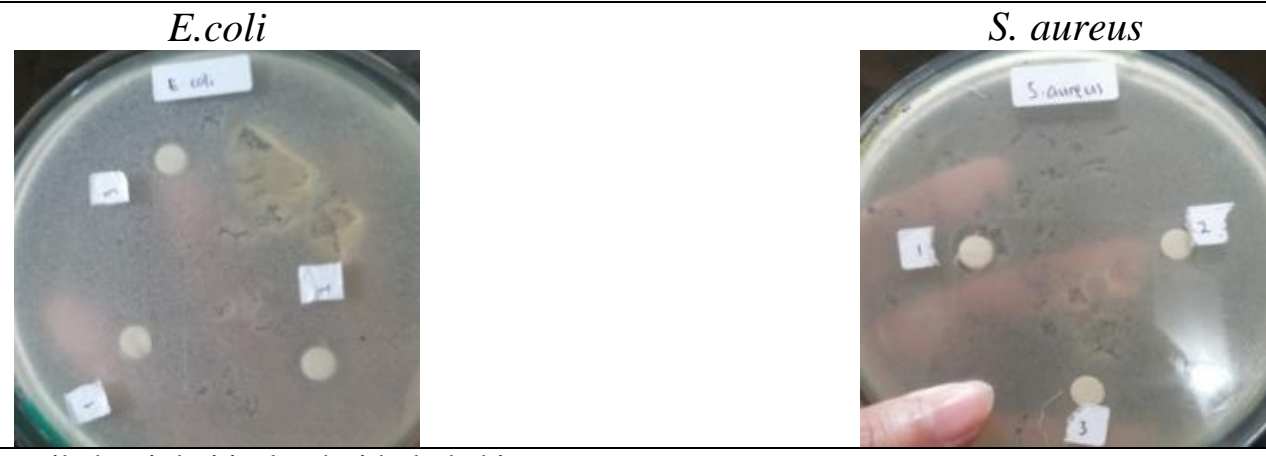

Gambar 5. Uji antibakteri dari isolat duri bulu babi

\section{Sensitivitas Bakteri Uji Terhadap Bakteri Isolasi Dari Duri Bulu Babi}

Hasil uji aktivitas antibakteri isolasi duri bulu babi terhadap bakteri uji memiliki hasil yang berbeda-beda (Tabel 5). Isolat 1 menghasilkan zona hambat dengan diameter $7 \mathrm{~mm}$ pada $E$. coli dan $11 \mathrm{~mm}$ pada $S$. aureus, sehingga lebih sensitif terhadap bakteri isolat 1 dibandingkan dengan $E$. coli yang kurang sensitif. Isolat 2 menghasilkan zona hambat dengan diameter $11 \mathrm{~mm}$ pada $E$. coli dan $8 \mathrm{~mm}$ pada $S$. aureus, sehingga bakteri E. coli merupakan bakteri yang lebih sensitif terhadap bakteri isolat 2 dibandingkan dengan $S$. aureus yang kurang sensitif. Sedangkan untuk isolat 3 menghasilkan zona hambat dengan diameter $7 \mathrm{~mm}$ pada $E$. coli dan $8 \mathrm{~mm}$ pada $S$. aureus, sehingga kedua bakteri uji ini memiliki tingkat sensitivitas yang relatif rendah terhadap isolat 3 .

Tabel 5. Hasil Uji Aktivitas Antibakteri Isolasi Duri Bulu Babi

\begin{tabular}{ccccc}
\hline \multirow{2}{*}{ No } & \multirow{2}{*}{ Bakteri Uji } & \multicolumn{3}{c}{ Diameter Zona Hambat (mm) } \\
& Isolat 1 & Isolat 2 & Isolat 3 \\
\hline \multirow{2}{*}{1} & E. coli & 7 & 11 & 7 \\
& Kategori & KS & S & KS \\
2 & S. aureus & 11 & 8 & 8 \\
& Kategori & $\mathrm{S}$ & $\mathrm{KS}$ & $\mathrm{KS}$ \\
\hline
\end{tabular}

\section{Keterangan :}

$\mathrm{S}$ : Zona hambat termasuk katagori Sensitif diameter zona hambat 10-20 mm

KS : Zona hambat termasuk katagori Kurang sensitif diameter zona hambat 5-10

$\mathrm{R}$ : Zona hambat termasuk katagori Resisten diameter zona hambat $<5 \mathrm{~mm}$ 


\section{Jurnal Biodjati, 3 (2) 2018

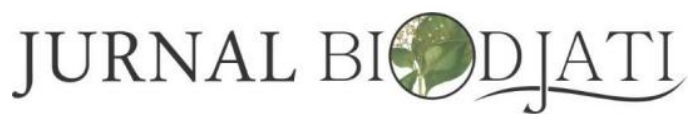

http://journal.uinsgd.ac.id/index.php/biodjati

Kesimpulan dari penelitian adalah Ekstrak bulu babi memiliki kemampuan sebagai antibakteri terhadap bakteri $E$. coli dan $S$. $a u$ reus meskipun aktivitas antibakteri tergolong rendah. Dari ketiga ekstrak bulu babi, ekstrak gonad memiliki aktivitas antibakteri tertinggi pada konsentrasi $80 \%$ dengan zona hambat 8,5 mm terhadap bakteri $E$. coli dan konsentrasi $80 \%$ dengan zona hambat $14 \mathrm{~mm}$ terhadap bakteri $S$. aureus.

\section{UCAPAN TERIMAKASIH}

Penulis mengucapkan terima kasih yang sebesar-besarnya kepada Rektor Universitas Padjadjaran yang telah memberikan fasilitas penelitian Academic Leadership Grant (ALG)

\section{DAFTAR PUSTAKA}

Abubakar, L., Wangi, C., Uku, J. \& Ndirangu, S. (2012). Antimicrobial Activity of Various Extracts of The Sea Urchin Tripneustes gratilla (Echinoidea). African Journal of Pharmacology and Therapeutics, 1(1), 19- 23.

Akerina, F. O., Nurhayati, T. \& Suwandy, R. (2015). Isolasi dan Karakterisasi Senyawa Antibakteri dari Bulu Babi. JPHPI, 18(1)

Brown, A. E. (2005). Laboratory Manual in General Microbiology: Microbiological Applications. US: McGraw-Hill Comp.

David, D. B. \& Rubinstein, E. (2003). Treatment of MRSA infection, In Fluit Ad $C$, and Franz-Josef Schitz (editors). MRSA: Current perspectives.

Fitria, B. (2009). Pewarnaan Gram (Gram positif dan Gram negatif) http://biobakteri.wordpress.com/2009/06/0 7/7-pewarnaan-gram-gram-positif-dangram-negatif.

Tor, H., Anita, Kjuul, K., Styrvold, O. B., Sandsdalen, E., Olsen, O. M. \& Stensvåg,
K. (2002). Antibacterial activity in Strongylocentrotus droebachiensis (Echinoidea), Cucumaria frondosa (Holothuroidea), and Asterias rubens (Asteroidea). Journal of Invertebrate Pathology, 81(2), 94-102.

Leimena, H. E. P. (2002). Potensi Pemanfaatan Beberapa Jenis Keong Laut (Moluska: Gastropoda). Jurnal Hayati, 9(3), 97-99.

Li, C., Haug, T., Stensvåg, K. (2010). Antimicrobial Peptides in Echinoderms. Invertebrate Survival Journal, 132-140.

Pranoto, E.N., Widodo, F. M. \& Delianis, P. (2012). Kajian Aktivitas Bioaktif Ekstrak Teripang Pasir (Holothuria scabra) Terhadap Jamur Candida albicans. Jurnal Pengolahan dan Bioteknologi Hasil Perikanan, 1(1), 1-8.

Rosyidah K., Nurmuhaimina, S. A., Komari, N. \& Astuti, M. D. (2010). Aktivitas Antibakteri Fraksi Saponin dari Kulit Batang Tumbuhan Kasturi (Mangifera casturi). Alchemy, 1(2), 53-103.

Septiadi, T., Pringgenies, D., Radjasa, O. K. (2013). Uji Fitokimia dan Aktivitas Antijamur Ekstrak Teripang Keling (Holoturia atra) Dari Pantai Bandengan Jepara Terhadap Jamur Candida albicans. Journal of Marine Research, 2(2), 76-84.

Stout, D. 2001. Bahan Anti Bakteri. dalam http://alumni.ipb.ac.id/content.php?idm=5 \&idwil=1\&news=253 Diakses pada 20 Mei 2016.

Uma, B. \& Parvathavarthini, R. (2010). Antibacterial Effect of Hexane Extract of Sea Urchin. International Journal of PharmTech Research, 2(3), 1677-1680.

Zakaria, I. J. (2013). Komunitas Bulu Babi (Echinoidea) di Pulau Cingkuak, Pulau Sikuai dan Pulau Selatan Sumatera Barat. Prosiding Semirata FMIPA Universitas Lampung, 1(1), 38-187. 